\title{
Short term toxicological analysis and effect of total replacement of wheat with Balanite aegyptiaca seed cake on albino rats
}

\author{
Ibironke A. Ajayi and Emmanuel N. Ifedi \\ Industrial Unit, Chemistry Department, Faculty of Sciences, University of Ibadan, Ibadan, Nigeria
}

\begin{abstract}
The short-term toxicological analysis of Balanite aegyptiaca seed cake (BASC) in rat feed has been carried out in order to determinate its suitability as an additive in feed supplement by comparing the effect of total replacement of wheat with BASC. The proximate analysis of BASC showed that it contained a high protein and a very low carbohydrate value of $49.32 \pm 0.13 \%$ and $11.02 \pm 0.18 \%$ respectively with an energy value of $1540.32 \pm 1.84 \mathrm{~kJ} / 100 \mathrm{~g}$. The in vivo experiment with albino rats fed with feed with its wheat constituent totally replaced by B. aegyptiaca seed cake lasted for eight weeks. The albino rats appeared to suffer no toxicological effect and their weekly monitoring showed good physical appearance. There were no significant differences between the haematological, histopathological and the blood chemistry results obtained for both the test and control groups.
\end{abstract}

Keywords: Balanite aegyptiaca seed cake, proximate composition, total replacement, wheat, rat.

\section{Introduction}

Balanite aegyptiaca is a desert plant that is widely distributed in the arid zone of Nigeria. It is also found in other African countries like Senegal and Sudan, as well as in India (Chothani \& Vaghasiya, 2011; Pandey, 2005). The tree is remarkable because it is available during the dry season, when foliage is difficult to obtain and prices of conventional feedstuff are more on the rise, and is found in many kinds of habitat, as it grows in a variety of soil types (Chothani \& Vaghasiya et al., 2011). Available reports on the nutritional and antinutritional profile of Balanite aegyptiaca seed powder showed that it contains a relatively high amount of protein and lipid (Samuel et al., 1997). However, in addition to the nutrients, the seed contains high level of antinutritional factors; tannins, oxalate and phytic acid (Chothani \& Vaghasiya, 2011). Tannins are secondary plant metabolites that are rich in phenolic hydroxyl groups and are also known to inhibit oxidation of alkaloids and morphine and form colored complexes with iron, thus reducing the bio-availability of this important mineral (Brune et al., 1989). All parts of the tree have a medicinal use including fruits, seeds, barks and roots. The most important is steroidal saponins, which yield diosgenin, a source of steroidal drugs, such as corticosteriods, contraceptives and sex hormones (Farid et al., 2002). Because of the high protein content in Balanite aegyptiaca kernel (Samuel et al., 1997), it could be utilized as an animal feed source if its toxic substances are eliminated and its protein is extracted and concentrated. Identifying a suitable processing method will enhance the opportunities for a versatile utilization of B. aegyptiaca seed kernel meal as an alternative, additional and economical source of protein in livestock feeding. The seed kernel is considered as an extremely useful edible product. It contains good quality oil and high protein content (Mohamed et al., 2002; Abu Al- Futuh, 1983). The debittered kernel is used as snacks by humans. The extracted oil has many uses while the remaining cake may be used as animal feed. This study was designed to examine the effect of total replacement of wheat with Balanite aegyptiaca seed cake in rat feed and to evaluate the toxicity, if any, on a short term basis using animal experiment.

\section{Seed material}

\section{Material and methods}

Balanite aegyptiaca seeds used for this study were purchased from Tundun wada market in Zaria, Kaduna State of Nigeria. The seeds were identified in the Botanical garden of the University of Ibadan. The seeds were screened to remove the defectives ones and soaked in a large bowl of water overnight to remove the glycoside pulp from seed coats. The seeds were then sun dried and crushed using a metal hammer to obtain its kernel.

\section{Sample preparation}

The Balanite aegyptiaca seed kernels were grounded into paste using a previously cleaned and dried mortar and pestle to increase extent of extraction of the oil. Oil was extracted from the seeds by solvent method using soxhlet extractor and $n$-hexane (b.pt $67-68{ }^{\circ} \mathrm{C}$ ) as the solvent. B. aegyptiaca seed cake (BASC) remaining after the oil extraction was air dried, pulverized and passed through a 200 mesh sieve to obtain the sample which was used as experimental material. 


\section{Proximate analysis}

Percentage moisture, crude fat, ash and crude fibre contents of BASC were determined following official methods. Nitrogen content of the seed cake was estimated using the micro-kjeldahl method as described by AOAC (1990) and crude protein was calculated $(\mathrm{N}$ x 6.25). Carbohydrate contents were determined by difference $[100-$ (moisture + protein + crude fat + ash + crude fiber $)]$. The calorific energy value was obtained according to the methods of Olaofe et al. (2009). This was done by multiplying the values of carbohydrate, protein and crude fat by the Atwater factors of 17, 17 and 37 respectively.

\section{Feed compounding}

The diets were prepared according to the procedure described by Souza et al. (2007) and Ajayi et al. (2013) with slight modification. The basic ingredients used were $2800.0 \mathrm{~g}$ of maize, $1274.7 \mathrm{~g}$ of soy bean, 231.0 $\mathrm{g}$ of calcium, $55.3 \mathrm{~g}$ of salt, $994.0 \mathrm{~g}$ of groundnut cake, $495.6 \mathrm{~g}$ of palm kernel cake, $495.6 \mathrm{~g}$ of wheat, $495.6 \mathrm{~g}$ of corn bran and $158.2 \mathrm{~g}$ of oyster shell for the control diet. Wheat was totally replaced with $495.6 \mathrm{~g}$ of BASC in the experimental diet while $495.6 \mathrm{~g}$ of wheat was incorporated in the control diet. Ingredients of the diets were mixed thoroughly with the mixing machine to obtain a homogenous mixture which was pelletized, weighed to be $7000.00 \mathrm{~g}$ for each diet and packed into two different transparent sterile plastic containers.

\section{Animal, diets and feeding}

Fourteen albino rats (weighing between 60-75 g) were used for this experiment. They were obtained from the animal house of Veterinary Department, University of Ibadan, Nigeria. The animals were divided into two groups of seven rats each and were fed for a period of 8 weeks before sacrifice. They were allowed to acclimatize for two weeks before the commencement of the experiment. During the 8 weeks of the experiment, the rats were fed with the compounded diets with unrestricted access to water. At the end of feeding period of eight weeks, the rats were fasted overnight and blood was collected by heart puncture under diethyl ether anesthesia for serum chemistry. Serum alanine aminotransferase and aspartate aminotransferase activities were determined by the method of Reitman and Frankel (1957) using commercial kits (Randox laboratories Co Atrium, UK). Serum creatinine, urea, total protein, albumin, globulin and albumin/globulin ratio (A/G) were also determined.

\section{Haematological analysis}

For haematological analysis, $3 \mathrm{ml}$ of blood were collected by cardiac puncture into heparinized vials and stored at $10^{\circ} \mathrm{C}$ for analysis the same day. The packed cell volume, haemaglobin concentration, red blood cell and white blood cell counts were determined. The differential WBC counts, mean corpuscular volume and mean corpuscular haemaglobin concentration were calculated (Jain 1986; Ajayi et al., 2013). Microhaemocrit capillary tubes were filled to two-thirds mark with well mixed venous blood. One end was sealed with plasticine. The sealed tubes were placed in microhaematocrit centrifuge and the safety cover securely screwed on. The sealed capillary tubes were centrifuged for 5 minutes at 10,000 revolutions per minutes. The volume of the red blood cell was read on the micro-haemocrit reader.

\section{Tissue pathology}

Histological analyses of the heart, liver, kidney, lungs, intestine, spleen and brain samples were carried out. Small portions of these tissues already harvested and stored in formalin were fixed and put through series of dehydration in graded concentration of xylene. They were embedded in wax, sectioned at $5 \mu$ and transferred to clean glass slides. The thin sections were stained with haemotoxylin and eosin $(\mathrm{H}$ and $\mathrm{E})$ dyes for examination under the light microscope for histological changes following the method outlined by Jain (1986).

\section{Statistical analysis}

Results were expressed as mean standard error. Organ weights, biochemical and hematological determinations were analyzed by student's t-test. A probability level of $\mathrm{p}<0.05$ was considered significant.

\section{Results and Discussion}

\section{Proximate analysis of Balanite aegyptiaca seed cake and compounded feed}

The result of the proximate composition of Balanite aegyptiaca seed cake (Table 2) showed high protein content $(49.32 \pm 0.03 \%)$. It is higher than the protein content of Fenugreek seed meal $(29.11 \%)$, soybean meal (44.03\%), wheat bran (14.98\%) and even corn meal (9.55\%) as reported by Ahmed et al. (2009). It is rich in crude fibre $(12.89 \pm 0.02 \%)$ but very low in carbohydrate content $(11.02 \pm 0.18 \%)$. This is similar to the report given by Samuel et al. (1997) for Balanite aegyptiaca seed kernel. The compounded feed was found to have a decrease in its crude protein and crude fibre content; however there was an increase in the ash and carbohydrate contents when compared to the seed cake (Table 2). 


\section{Feed intake and body weight changes}

Feed consumption and resultant change in body weight of test and control groups are presented on Table 3. There was a gradual increase in the quantity of feed consumed by rats in the two groups till the fourth week, a slight decrease in the fifth week and continues afterwards. There was steady but not rapid increment in the body weight of the rats during the experimental period. Significant differences were noted within the groups for body weights of rats during weeks zero and one. For week eight, there was no significant difference in the body weight of rats $(\mathrm{p}<0.05)$ in the two groups.

\section{Physical appearance}

All the rats were healthy throughout the eight weeks of the experiment. Their body did not smell and they all showed normal hair structure. No mortality was recorded in any of the groups. Ajayi et al. (2007) gave similar report for rat fed with Garcinia mangostana seed oil.

\section{Organ weights}

There was no significant difference in the weight of the liver, kidney, heart and spleen of the control and experimental rats as shown on Table 4. Liver weight was from $4.74 \pm 0.63 \mathrm{~g}$ (control group) to $4.47 \pm 0.47$ $\mathrm{g}$ (experimental group). $3.92 \pm 0.19 \mathrm{~g}$ to $3.95 \pm 0.21 \mathrm{~g}$ has been previously reported as liver weight for rats fed with crude Balanite aegyptiaca seed oil in rat (Obida et al., 2009). The weight of the heart, brain, and kidney of $0.53 \pm 0.0 \mathrm{~g}, 1.41 \pm 0.10 \mathrm{~g}$ and $0.9 \pm 0.06 \mathrm{~g}$ obtained respectively in the control group are similar to the weight obtained in the experimental group. The spleen weight of the control rats is $0.56 \pm 0.08 \mathrm{~g}$ while that of the test rats $0.63 \pm 0.35 \mathrm{~g}$. On the whole, there was no significant difference between the weight of the organs of the test rats and those of the control $(\mathrm{p}<0.05)$.

\section{Haematological analysis}

Table 5 shows the result of haematological analysis of BASC on rats. The parameters obtained for rats in the control and experimental groups were comparable. Haemoglobin concentration in test group (14.53 $\pm 0.34 \%)$ is significantly different to that of the control group $(13.51 \pm 0.83 \%)$. Bienat et al., (1997) obtained $13.88 \pm 0.1 \%$ for diet without cholesterol addition of Oenothra paradoxa seed oil. Vishnu et al., (2010) obtained a concentration ranging from $13.83 \pm 0.98 \%$ to $14.12 \pm 0.41 \%$ for G.mangostana pericarp extracts in rats at 1 $\mathrm{g} / \mathrm{kg}, 2 \mathrm{~g} / \mathrm{kg}$, and $3 \mathrm{~g} / \mathrm{kg}$ respectively. There was a significance difference in the platelet count and all the other parameters did not differ significantly from each other in the two groups. The values obtained in this study are similar to what was reported in the toxicity study of Garcinia mangostana pericarp extract and seed cake on rat (Vishnu et al., 2010 and Ajayi et al., 2013).

\section{Serum biochemical parameters}

Table 6 shows the result of serum biochemical parameters in rats fed with BASC for eight weeks. The result showed no significant $(\mathrm{p}>0.05)$ changes in serum ALT and AST activities, total protein, albumin and A/G ratio between the control and treated groups. The absence of significant changes in ALT and other related indicators such as AST, total protein, albumin and A/G ratio may suggest that the hepatotoxic effect of BASC on the rats is not significant. The insignificant rise in serum urea and creatinine is suggestive of normal functional kidney.

\section{Histopathological analysis}

The pathology result showed no major complications and no significant differences on the tissues of the rats in both groups (Table 7). No lesion was observed in the heart and liver of the rats in the control and test groups but in the brain, the endothelia cells are swollen and prominent in the both group. The renal blood vessels are moderately congested in the kidney for the control group while no visible lesion was observed for the test group. This shows that Balanite aegyptiaca seed cake might not be harmful to most organs and tissues of rats fed it.

\section{Conclusion}

Balanite aegyptiaca seed cake has high crude protein content but it is low in carbohydrate and crude fibre. The overall result obtained from the total replacement of wheat with B. aegyptiaca seed cake in albino rat feed suggests the possibility that B. aegyptiaca seed cake could successful be used to replace wheat in rat diet with other supplements. This will reduce the competition on wheat as majority of diabetic patients and aged people base their meal on wheat. 


\section{Acknowledgement}

The authors thank the Department of Chemistry, Faculty of Science and Department of Veterinary Pathology, Faculty of Veterinary of University of Ibadan, Ibadan, Nigeria for making their facilities available.

\section{References}

[1]. Abu-Al-Futuh, I. M. (1983). Balanites aegyptiaca: An unutilized raw material potential ready for agro-industrial exploitation. UNIDO Document no. 12419 project TF/INT/77/021. UNIDO of the United Nations.

[2]. Ahmed, A. M. M., Mohammad, H. A., Amani, M. \& Asmaa, S. (2009). Effect of using dried fenugreek seeds as natural feed additives on growth performance, feed utilization, whole- body composition and entropathogenic Aeromonas hydrophila-challinge of monsex nile tilapia O. niloticus (L) fingerlings. Australian Journal of Basic and Applied Sciences 3: $1234-1245$.

[3]. Ajayi, I. A., Oderinde, R.A., Ogunkoya, B.O., Egunyomi, A., and Taiwo, V.O. (2007). Chemical analysis and preliminary toxicological evaluation of Garcinia mangostana seeds and seeds oil. Food Chemistry 101: 999-1004.

[4]. Ajayi, I. A., Ifedi, E. N. \& Aghanu, V. N. (2013). Amino acid Analysis and preliminary toxicological evaluation of Garcinia mangostana seed cake. Global Journal of Sciences $\quad$ Frontier Research 13: 17-22.

[5]. AOAC (1990). Official methods of analysis, Association of Official Analytical Chemists, Washington, D.C., USA. 15th Edition, pp. $807-928$

[6]. Brune, M., Rossander, L., \& Haliberg, L. (1989). Iron absorption and phenolic compounds: importance of different phenolic structures. European Journal of Clinical Nutrition 43(8): 547-557.

[7]. Chothani, D. L., \& Vaghasiya, H. U. (2011). A Review on Balanites aegyptiaca Del (desert date): Phytochemical constituents, traditional uses, and pharmacological activity. Pharmacogical Review 5: 55-62.

[8]. Farid, H., Haslinger, E., Kunert, O., Wegner, C. \&Hamburger, M. (2002). New steroidal glycosides from Balanites aegyptiaca. Helvetica Chimica Acta 88: 1019-1026.

[9]. Jain, N. L. 1986. Schalmes Veterinary Haematology. Volume III, 4th Edition, Lea and Ferbiger, Philadelphia. pp. 281

[10]. Mohamed, A. M, Wolf, W. \& Speiss, W. (2002). Physical, morphological and chemical characteristics, oil recovery and fatty acid composition of Balanites aegyptiaca kernels. Plant Foods for Human Nutrition 57: 179-189.

[11]. Obidah, W., Nadro, M. S., Tiyafo, G. O. \& Wurochekke, A. U. (2009). Toxicity of crude Balanites aegyptiaca seed oil in rats. Journal of American Science 5(6):13-16.

[12]. Olaofe, O., Ekuagbere, A. O. \& Ogunlade, L. (2009). Chemical, amino acid composition and functional properties of calabash seed's kernel. Bulletin of Pure and Applied Sciences 28(1-2): 13-24.

[13]. Pandey, C. N. (2005). Medicinal Plants of Gujarat. Gujarat, India: Gujarat Ecological Education and Research Foundation. pp. 387.

[14]. Samuel, A. L., Temple, J. V. \& Ladeji, O. (1997). Chemical and nutritional evaluation of the seed kernel of Balanites aegyptiaca . Nigerian Journal of Biotechnology 8: 57-63.

[15]. Souza, A. R. de., Martins, L. P., Faira, L. C. de., Martins M. E. P., Fereira, R. N., Silva, A. M. L. da., Gil, E. S. \& Conceição, E. C. da. (2007). Studies on the bioavailability of zinc in rats supplemented with two different zinc-methionine compounds. Latin American Journal of Pharmacy 26(6): 825-830. 48.

[16]. Vishnu, P. V., Sankari, G., Mallika, J., Surapaneni, K. M., Aishwarya, T. S., Saraswathi, P., Chandra, S. \& Gopan, V. S. (2010). Auto fluorescence and fourier transform - infra red (FTIR) spectral investigation on diethyl nitrosamine (Den) induced hepatocellular carcinoma, treated with pericarp extract of Garcinia mangostana Linn. in rats. Journal of and Diagnostic Research 4: 3289-3297.

Table 1: Composition of experimental diets

\begin{tabular}{lcclc}
\hline Ingredient & \% & Amount $(\mathbf{g})$ & Control & Experimental \\
\hline Salt & 0.79 & 55.30 & 55.30 & 55.30 \\
Oyster Shell & 2.26 & 158.2 & 158.2 & 158.2 \\
Bone & 3.30 & 231.000 & 231.000 & 231.00 \\
Corn Bran & 7.08 & 495.6 & 495.6 & 495.6 \\
Palm kernel cake & 7.08 & 495.6 & 495.6 & 495.6 \\
Wheat & 7.08 & 495.6 & 495.6 & - \\
B. aegyptiaca seed cake & - & - & - & 495.6 \\
Ground nut cake & 14.20 & 994.00 & 994.00 & 994.00 \\
Soy bean & 18.21 & 1274.7 & 1274.7 & 1274.7 \\
Maize & 40.00 & 2800 & 2800 & 2800 \\
Total feed compounded & $100 \%$ & $7000 \mathrm{~g}$ & $7000 \mathrm{~g}$ & $7000 \mathrm{~g}$ \\
& & $7 \mathrm{~kg}$ & $7 \mathrm{~kg}$ & $7 \mathrm{~kg}$ \\
\hline
\end{tabular}

Table 2: Proximate composition of Balanite aegytiaea seed cake, control and experimental diets

\begin{tabular}{llll}
\hline PARAMETER $^{*}$ & BASC & Control diet & Experimental diet \\
\hline Moisture content & $8.45 \pm 0.03$ & $10.12 \pm 0.16^{\mathrm{a}}$ & $9.70 \pm 0.12^{\mathrm{a}}$ \\
Protein content & $49.32 \pm 0.13$ & $13.63 \pm 0.04^{\mathrm{b}}$ & $24.45 \pm 0.13^{\mathrm{a}}$ \\
Crude fat & $13.92 \pm 0.04$ & $18.24 \pm 0.96^{\mathrm{a}}$ & $13.68 \pm 0.02^{\mathrm{b}}$ \\
Crude fibre & $12.89 \pm 0.02$ & $7.95 \pm 0.07^{\mathrm{a}}$ & $9.75 \pm 0.05^{\mathrm{a}}$ \\
Ash content & $4.40 \pm 0.02$ & $13.09 \pm 0.17^{\mathrm{a}}$ & $17.16 \pm 0.01^{\mathrm{a}}$ \\
Carbohydrate & $11.02 \pm 0.18$ & $36.77 \pm 0.47^{\mathrm{a}}$ & $25.25 \pm 0.01^{\mathrm{b}}$ \\
Energy & $1540.22 \pm 1.84$ & $1535.05 \pm 15.83^{\mathrm{a}}$ & $1351.06 \pm 2.1^{\mathrm{b}}$ \\
\hline
\end{tabular}

"Values in the same row with different superscripts are significantly different at $\mathrm{P}<0.05$ 
Table 3: Weekly feed consumption by rats and their body weights $(\mathrm{g})$

\begin{tabular}{ccccc}
\hline \multirow{2}{*}{ Weekly } & \multicolumn{2}{c}{ Feed consumed } & & \multicolumn{2}{c}{ Body weight/ rat $^{*}$} \\
\cline { 2 - 5 } & Control & Experimental & Control & $74.21 \pm 2.89^{\mathrm{a}}$ \\
1 & - & - & $77.11 \pm 2.67^{\mathrm{a}}$ & $82.86 \pm 2.67^{\mathrm{b}}$ \\
2 & 560 & 570 & $83.57 \pm 3.78^{\mathrm{a}}$ & $95.00 \pm 5.77^{\mathrm{b}}$ \\
3 & 640 & 620 & $95.00 \pm 5.00^{\mathrm{a}}$ & $106.43 \pm 3.78^{\mathrm{b}}$ \\
${ }^{\mathrm{b}} 4$ & 640 & 640 & $112.86 \pm 10.75^{\mathrm{a}}$ & $117.86 \pm 3.9^{\mathrm{a}}$ \\
5 & 650 & 665 & $108.57 \pm 7.42^{\mathrm{a}}$ & $118.56 \pm 4.64^{\mathrm{b}}$ \\
6 & 600 & 650 & $112.14 \pm 9.06^{\mathrm{a}}$ & $113.57 \pm 7.5^{\mathrm{a}}$ \\
7 & 680 & 720 & $115.71 \pm 12.72^{\mathrm{a}}$ & $118.57 \pm 10.69^{\mathrm{a}}$ \\
8 & 705 & 735 & $117.86 \pm 3.2^{\mathrm{a}}$ & $122.14 \pm 14.99^{\mathrm{a}}$ \\
\hline
\end{tabular}

${ }^{*}$ Values in the same row with different superscripts are significantly different at $\mathrm{P}<0.05$

Table 4: Organ weights of rats $(\mathrm{g})^{*}$

\begin{tabular}{lcc}
\hline \multicolumn{1}{c}{ Tissue } & Control & Experimental \\
\hline Brain & $1.41 \pm 0.10^{\mathrm{a}}$ & $1.44 \pm 0.09^{\mathrm{a}}$ \\
Liver & $4.74 \pm 0.63^{\mathrm{a}}$ & $4.67 \pm 0.47^{\mathrm{a}}$ \\
Spleen & $1.06 \pm 0.25^{\mathrm{a}}$ & $1.24 \pm 0.35^{\mathrm{a}}$ \\
Heart & $0.53 \pm 0.05^{\mathrm{a}}$ & $0.51 \pm 0.28^{\mathrm{a}}$ \\
Lung & $0.56 \pm 0.08^{\mathrm{a}}$ & $0.63 \pm 0.35^{\mathrm{a}}$ \\
Kidney & $0.9 \pm 0.06^{\mathrm{a}}$ & $0.88 \pm 0.09^{\mathrm{a}}$ \\
Intestine & $1.36 \pm 0.29^{\mathrm{a}}$ & $1.56 \pm 0.20^{\mathrm{b}}$ \\
\hline Means in the same row having the same letter are not significantly different
\end{tabular}

Table 5: Result of haematological analysis of control and experimental rats ${ }^{*}$

\begin{tabular}{lll}
\hline Parameters & Control & Experimental \\
\hline PVC & $40.29 \pm 1.30^{\mathrm{a}}$ & $40.29 \pm 0.98^{\mathrm{a}}$ \\
$\mathrm{Hb}$ & $13.51 \pm 0.83^{\mathrm{a}}$ & $14.53 \pm 0.34^{\mathrm{b}}$ \\
RBC & $6.48 \pm 0.50^{\mathrm{a}}$ & $6.30 \pm 0.44^{\mathrm{a}}$ \\
WBC & $6685.71 \pm 718.81^{\mathrm{a}}$ & $7771.43 \pm 710.10^{\mathrm{b}}$ \\
MCV & $59.17 \pm 2.52^{\mathrm{a}}$ & $58.93 \pm 5.15^{\mathrm{a}}$ \\
MCH & $20.85 \pm 0.79^{\mathrm{a}}$ & $19.92 \pm 1.07^{\mathrm{a}}$ \\
MCHC \% & $33.53 \pm 1.11^{\mathrm{a}}$ & $32.92 \pm 0.52^{\mathrm{a}}$ \\
Lymphocytes \% & $70.14 \pm 6.49^{\mathrm{a}}$ & $70.43 \pm 8.18^{\mathrm{a}}$ \\
Neutrophil \% & $28.06 \pm 6.53^{\mathrm{a}}$ & $27.97 \pm 7.06^{\mathrm{a}}$ \\
Mionocytes \% & $0.71 \pm 0.56^{\mathrm{a}}$ & $0.71 \pm 0.65^{\mathrm{a}}$ \\
Eosinophil \% & $1.14 \pm 0.50^{\mathrm{a}}$ & $1.15 \pm 1.15^{\mathrm{a}}$ \\
Platelets & $125285.71 \pm 35,831.01^{\mathrm{a}}$ & $122000 \pm 13.759,84^{\mathrm{a}}$ \\
\hline
\end{tabular}

${ }^{*}$ Values in the same row with different superscripts are significantly different at $\mathrm{P}<0.05$

Table 6: serum biochemistry parameters on rat fed with Balanite aegyptiaca seed cake ${ }^{*}$ The

\begin{tabular}{lll}
\hline Parameters & Control & Experimental \\
\hline Total protein & $6.6 \pm 0.30^{\mathrm{a}}$ & $6.93 \pm 0.11^{\mathrm{a}}$ \\
Albumin & $3.63 \pm 0.26^{\mathrm{a}}$ & $4.0 \pm 0.1^{\mathrm{a}}$ \\
Globulin & $2.86 \pm 0.15^{\mathrm{a}}$ & $2.67 \pm 0.28^{\mathrm{a}}$ \\
AL/Globulin & $1.17 \pm 0.06^{\mathrm{a}}$ & $1.47 \pm 0.7^{\mathrm{b}}$ \\
AST & $3.9 \pm 1.00^{\mathrm{a}}$ & $4.1 \pm 1.00^{\mathrm{a}}$ \\
ALT & $26.67 \pm 0.58^{\mathrm{a}}$ & $30.67 \pm 0.58^{\mathrm{b}}$ \\
ALP & $81.33 \pm 3.51^{\mathrm{a}}$ & $103 \pm 23.64^{\mathrm{b}}$ \\
Urea & $16 \pm 1.00^{\mathrm{a}}$ & $16 \pm 1.00^{\mathrm{a}}$ \\
Creatinine & $0.67 \pm 0.01^{\mathrm{a}}$ & $0.8 \pm 0.2^{\mathrm{b}}$ \\
\hline
\end{tabular}

${ }^{*}$ Values in the same row with different superscripts are significantly different at $\mathrm{p}<0.05$

Table 7: Histopathology examination of rat tissues

\begin{tabular}{lll}
\hline Parameters & Control Group & Experimental Group \\
\hline Heart & No visible Lesion & No visible Lesion \\
Brain & The endothelia cell are swollen and prominent & $\begin{array}{l}\text { The endothelia cell are swollen } \\
\text { and prominent }\end{array}$ \\
Liver & No visible Lesion & No visible Lesion \\
Kidney & The renal blood vessels are moderately & No visible Lesion \\
& Congested. & \\
\hline
\end{tabular}




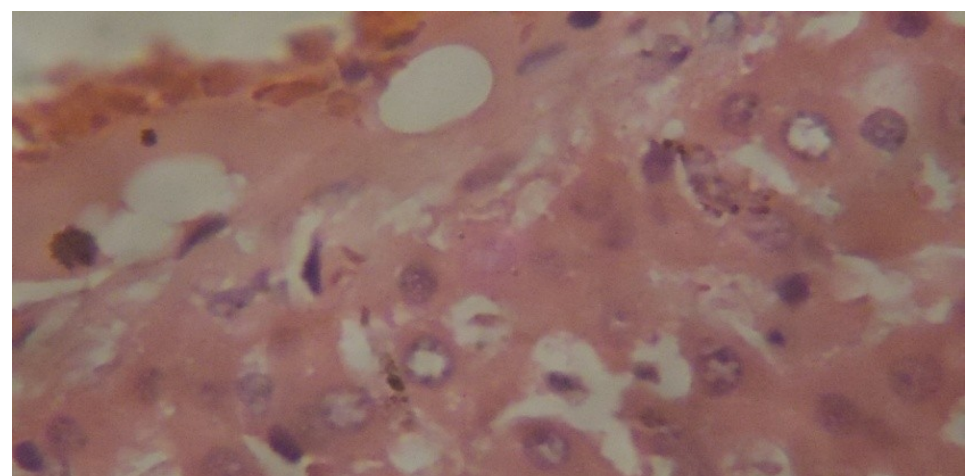

Fig 1. Photomicrograph of the kidney showing were renal blood vessels are moderately congested. (x550).

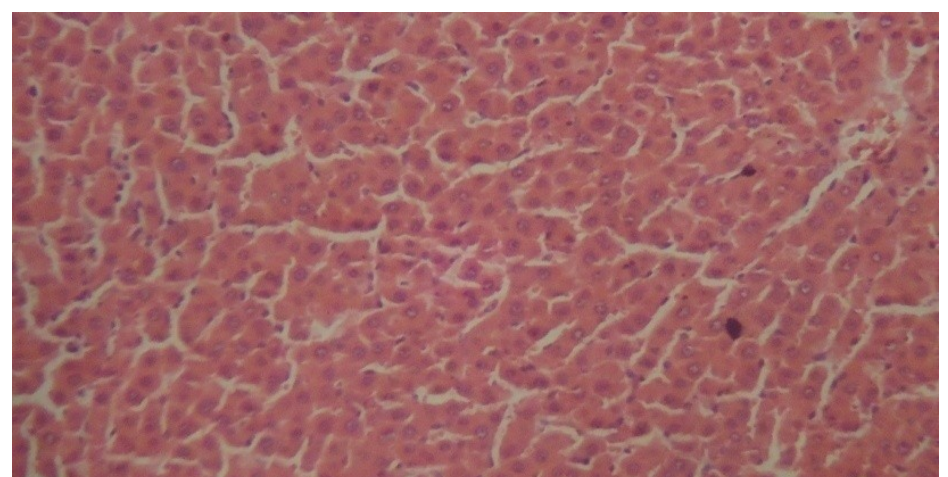

Fig 2. Photomicrograph of the Kidney of experimental rats howing no lesion (x550). 